\title{
Tellurium, selenium and cobalt enrichment in Neoproterozoic black shales, Gwna Group, UK: Deep marine trace element enrichment during the Second Great Oxygenation Event
}

\author{
Joseph G. T. Armstrong ${ }^{1}$ (D) | John Parnell ${ }^{1}$ | Liam A. Bullock $^{1} \mid$ Magali Perez $^{2}$ | \\ Adrian J. Boyce $^{3}$ | Jorg Feldmann ${ }^{2}$
}

\author{
${ }^{1}$ School of Geosciences, University of \\ Aberdeen, Aberdeen, UK \\ ${ }^{2}$ Trace Element Speciation Laboratory \\ (TESLA), Department of Chemistry, \\ University of Aberdeen, Aberdeen, UK \\ ${ }^{3}$ Scottish Universities Environmental \\ Research Centre, East Kilbride, Glasgow, \\ UK

\section{Correspondence} \\ Joseph G. T. Armstrong, School of \\ Geosciences, University of Aberdeen, \\ Aberdeen, UK. \\ Email: joseph.armstrong@abdn.ac.uk

\section{Funding information} \\ Natural Environment Research Council, \\ Grant/Award Number: IP-1631-0516, NE/ \\ M010953/1
}

\begin{abstract}
Black shales of the late Neoproterozoic Gwna Group (570-580 Ma), UK, contain enrichments of tellurium (Te), selenium (Se) and cobalt (Co) relative to average shale compositions. The Te and Co enrichments bear comparison with those of ferromanganese crusts in the modern deep ocean. Gwna Group deposition coincides with the Second Great Oxidation Event, which had a significant effect on trace element fixation globally. Selenium and Te concentrations within these black shales indicate increased continental weathering rates, high biological productivity and corresponding increases in atmospheric $\mathrm{O}_{2}$ concentrations. Cobalt, nickel (Ni) and arsenic (As) enrichments in this succession are secondary mineralisation phases. Demand for many of the trace elements found enriched in the Gwna Group black shales make their mechanisms of accumulation, and variations through the geological record, important to understand, and suggests that new resources may be sought based on black shale protoliths from this period.
\end{abstract}

\section{1 | INTRODUCTION}

Increasing market demand for previously low-demand 'critical metals' necessitates improved understanding of their enrichment processes, ensuring a reliable supply of raw material in the future. Demand for the elements $\mathrm{Te}$ and Se has been driven by their potential use in large-scale environmental technologies, particularly solar cells (Chelvanathan, Hossain, \& Amin, 2010; Morales-Acevedo, 2006). Demand for cobalt has also increased due to its use in high-capacity batteries (Leite et al., 2017). A reliable supply of these elements is vital to allow growth of new technology, although these elements have restricted supplies from current sources (Nassar, Graedel, \& Harper, 2015; Vesborg \& Jaramillo, 2012).

Deep marine ferromanganese crusts are considered key targets for seafloor mining due to their abundance in a range of trace elements, specifically Te and Co (Hein, Conrad, \& Staudigel, 2010; Hein, Koschinsky, Bau, \& Roberts, 2000; Hein, Koschinsky, \& Halliday, 2003). Tellurium is fractionated from its common partner Se in oxidising conditions by adsorption on iron oxide, while Se is soluble in oxidising conditions (Kashiwabara et al., 2014) and not enriched in ferromanganese crusts. The expense and environmental impact of seafloor mining are key issues in the extraction of ferromanganese crusts, which may become utilised as demand for Co and Te increases.

Carbon-rich sedimentary rocks, especially black shales, have elevated concentrations of $\mathrm{Co}$, Te, Se and many other trace elements, due to their anoxic depositional conditions and commonly sulphiderich composition (Hu \& Gao, 2008; Large et al., 2015; Parnell, Brolly, Spinks, \& Bowden, 2016). While concentrations of these critical elements are well below ore grade, the extensive nature of shales makes them a potentially large sink of trace elements. We compare 


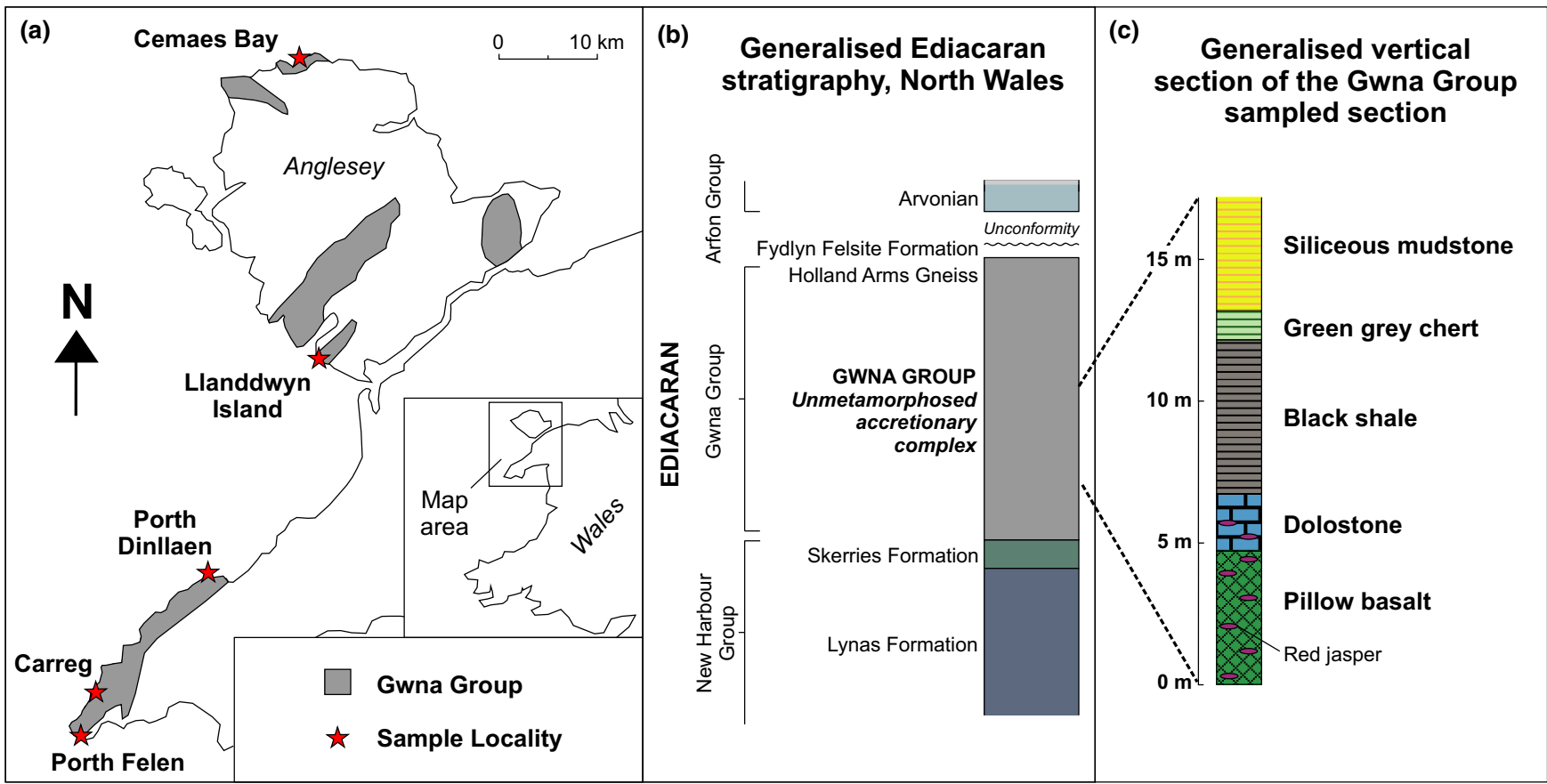

FIGURE 1 (a) Area map of NW Wales, showing distribution of Gwna Group stratigraphy (Adapted from Horák \& Evans, 2011). (b) Generalised Stratigraphic Section of Ediacaran Age, N. Wales (Adapted from Howells, 2007; Kawai et al., 2007, 2008) (c) Generalised vertical section of Gwna Group sampled section (Adapted from Sato et al., 2015) [Colour figure can be viewed at wileyonlinelibrary.com]

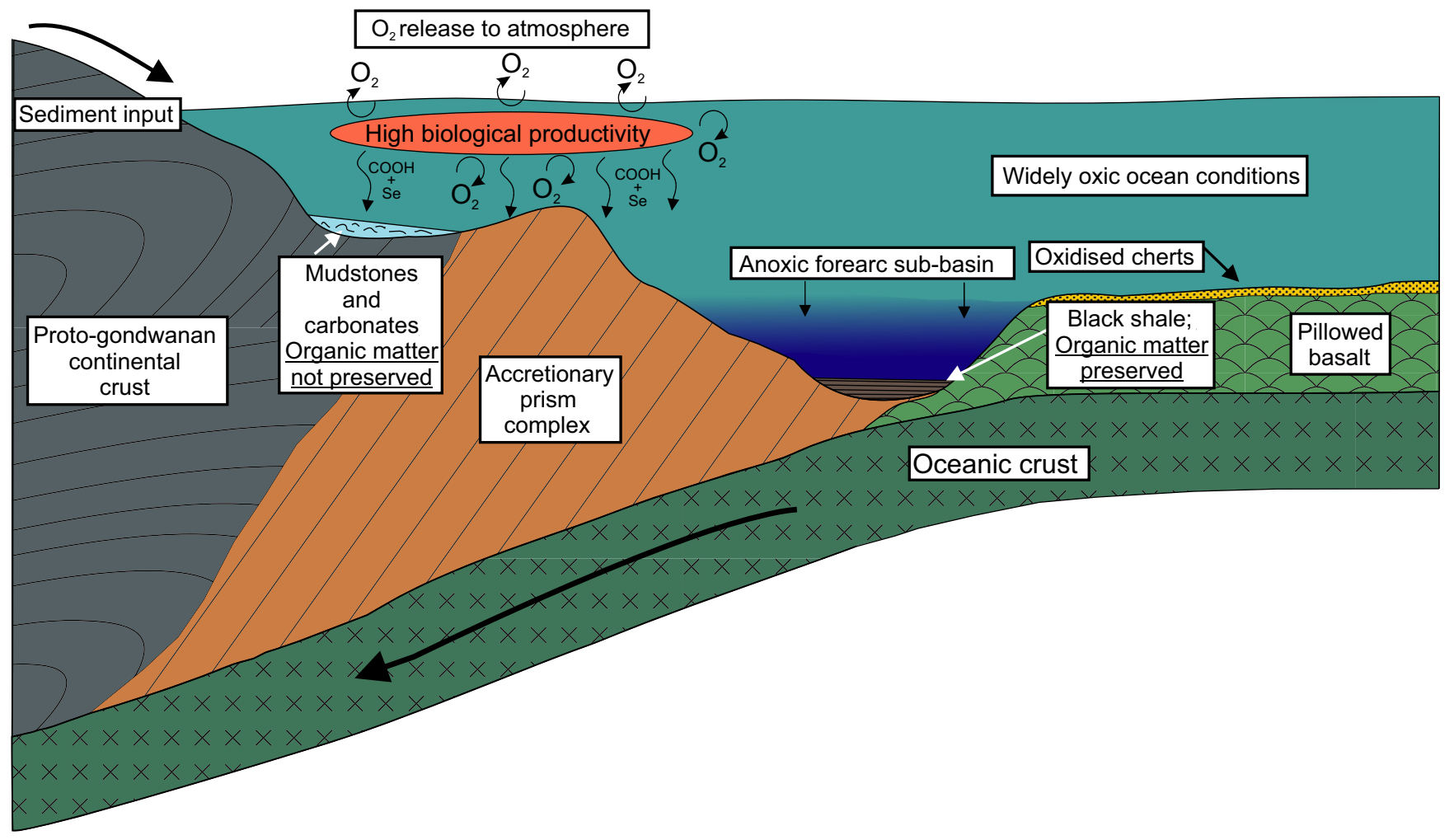

FIGURE 2 Depositional model for Gwna Group sequence after Maruyama et al. (2010). Gwna Group melange formation in accretionary wedge on western margin of Gondwana. Black shales deposited in anoxic forearc trench. Oxic depositional environments shown for deposition of carbonates, mudstones, sandstones and cherts of the Gwna Group prior to accretion. (Campbell \& Squire, 2010; Horák \& Evans, 2011; Meert \& Lieberman, 2008; Pogge von Strandmann et al., 2015) [Colour figure can be viewed at wileyonlinelibrary.com] 


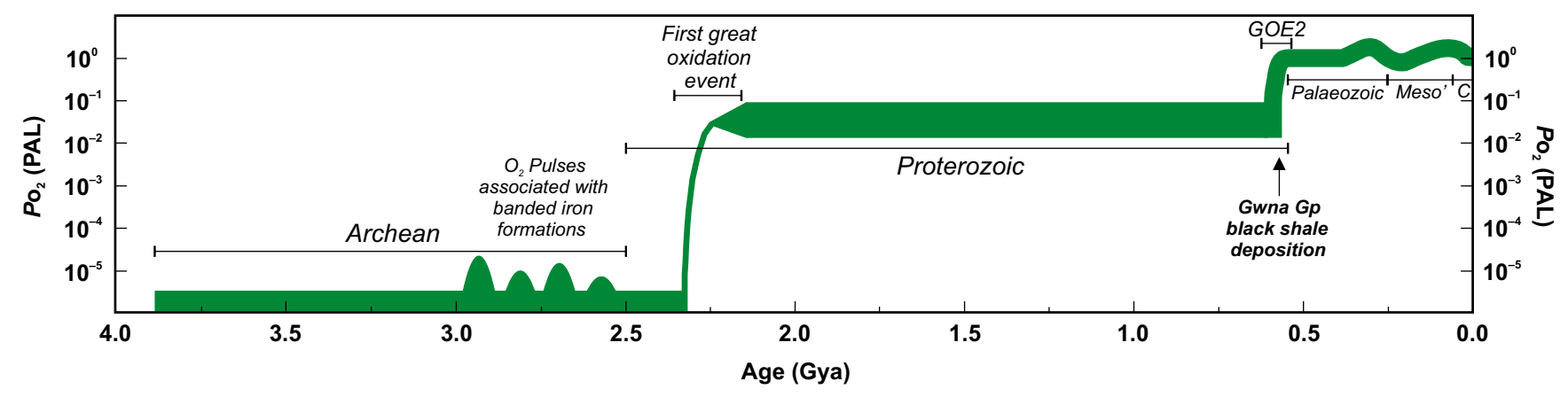

FIG URE 3 Global atmospheric oxygen evolution of Earth through time after Lyons et al. (2014). Oxygen concentration given relative to present atmospheric levels $-\mathrm{PO}_{2}$ (PAL). Present atmospheric levels stated as $100=1$. Geological age data provided (Gradstein \& Ogg, 2012) and timings of major oxygenation events shown (Lyons et al., 2014). Gwna Group black shale depositional range (570-580 Ma) indicated (Sato et al., 2015) [Colour figure can be viewed at wileyonlinelibrary.com]

the geochemistry of the late Neoproterozoic (Ediacaran), 570$580 \mathrm{Ma}$ (Sato et al., 2015) Gwna Group black shales, N. Wales (Figure 1a) to that of modern-day ferromanganese crusts and assess the wider geological significance of these Precambrian deposits in relation to global atmospheric oxygenation.

\section{2 | GEOLOGICAL SETTING}

The Gwna Group (Figure 1) is a 'melange' of Neoproterozoic deep-sea sedimentary lithologies deposited between 860 and 570 Ma (Horák \& Evans, 2011). Accretion of the original oceanic sediments and underlying pillowed basalts occurred at latest 550-560 Ma as part of a forearc complex, during the subduction of the lapetus Ocean on the ProtoGondwanan western margin (Figure 2) (Horák \& Evans, 2011; Maruyama, Kawai, \& Windley, 2010; Meert \& Lieberman, 2008). The Gwna Group consists of basalt, sandstones, dolomitic carbonates, laminated mudstones and cherts (Figure 1c), representing a range of water depths and redox conditions. Reducing conditions are represented by black shales, while oxygenated conditions are implied by red mudstones and hematitic red cherts (Figure 2). The carbonates are locally stromatolitic and oolitic (Horák \& Evans, 2011; Wood \& Nicholls, 1973), indicating periodically shallow water levels. Abundant pyrite occurs in the black shales, basalts and carbonates. Black shale deposition, 570-580 Ma (Sato et al., 2015), closely followed the Second Great Oxidation Event (GOE2) of the late Neoproterozoic, when atmospheric oxygen concentrations increased from $10 \%$ PAL (present atmospheric level) to $60 \%$ 100\% PAL (Campbell \& Squire, 2010; Canfield, 2005) (Figure 3). At this time, Wales was situated on the Avalonian landmass, at approximately $30^{\circ} \mathrm{S}$ latitude (Kawai et al., 2008).

\section{3 | METHODOLOGY}

Samples of the Gwna Group succession (Figure 1c) were collected from sites across Anglesey and the Lleyn Peninsula (Table 1). Wholerock samples were analysed for trace element contents using inductively coupled plasma-atomic emission spectrometry (ICP-AES) and
TABLE 1 Details of Gwna Group sampling sites, UK

\begin{tabular}{lcl} 
Sample site & Latitude/Longitude & Lithologies collected \\
\hline Porth Felen & $52^{\circ} 46^{\prime} 58.55^{\prime \prime} \mathrm{N} /$ & Black Shale \\
& $4^{\circ} 44^{\prime} 5.25^{\prime \prime} \mathrm{W}$ & \\
\hline Cemaes Bay & $53^{\circ} 24^{\prime} 52.48^{\prime \prime} \mathrm{N} /$ & Grey Shale; Massive Sulphide \\
& $4^{\circ} 27^{\prime} 11.44^{\prime \prime} \mathrm{W}$ & \\
\hline Porth Dinllaen & $52^{\circ} 56^{\prime} 32.89^{\prime \prime} \mathrm{N} /$ & Red Mudstone; Pyritic Basalt \\
& $4^{\circ} 34^{\prime} 8.03^{\prime \prime} \mathrm{W}$ & \\
\hline Llanddwyn Island $53^{\circ} 8^{\prime} 8.23^{\prime \prime} \mathrm{N} /$ & Pyritic Basalt \\
& $4^{\circ} 24^{\prime} 54.90^{\prime \prime} \mathrm{W}$ & \\
& $52^{\circ} 49^{\prime} 55.49^{\prime \prime} \mathrm{N} /$ & Red Mudstone \\
& $4^{\circ} 43^{\prime} 50.82^{\prime \prime} \mathrm{W}$ & \\
\hline
\end{tabular}

inductively coupled plasma-mass spectrometry (ICP-MS), at ALS Laboratories, Loughrea, Ireland. Each rock sample was milled and homogenised and $0.5 \mathrm{~g}$ was partially digested using aqua regia. Samples were analysed for elemental abundances using ICP-MS and ICP-AES. Inter-element spectral interferences were accounted for. $1 \sigma$ standard variabilities for calibration standards are supplied in Data S1. This method represents a partial leach of the rock, with digestion of all phases except silicates. Aqua regia digestion is considered to best represent the seawater depositional component of black shales (Xu, Hannah, Bingen, Georgiev, \& Stein, 2012).

Sulphides were extracted and analysed for their isotopic composition using standard techniques (Bullock et al., 2018). Data are reported (Table 2$)$ in $\delta^{34} \mathrm{~S}$ notation as per mille (\%VCDT).

Scanning electron microscopy (SEM) was performed using a Zeiss Gemini-300 FEG-SEM, to determine key sites of trace element mineralisation.

Laser ablation-inductively coupled mass spectrometry (LA-ICP-MS) was utilised to locate and quantify concentrations of trace elements in the black shales. LA-ICP-MS method can be found in Parnell et al. (2017).

\section{4 | RESULTS}

Tellurium, Se, Mo, As and Co concentrations in the Gwna Group black shale are at least an order of magnitude greater than average 


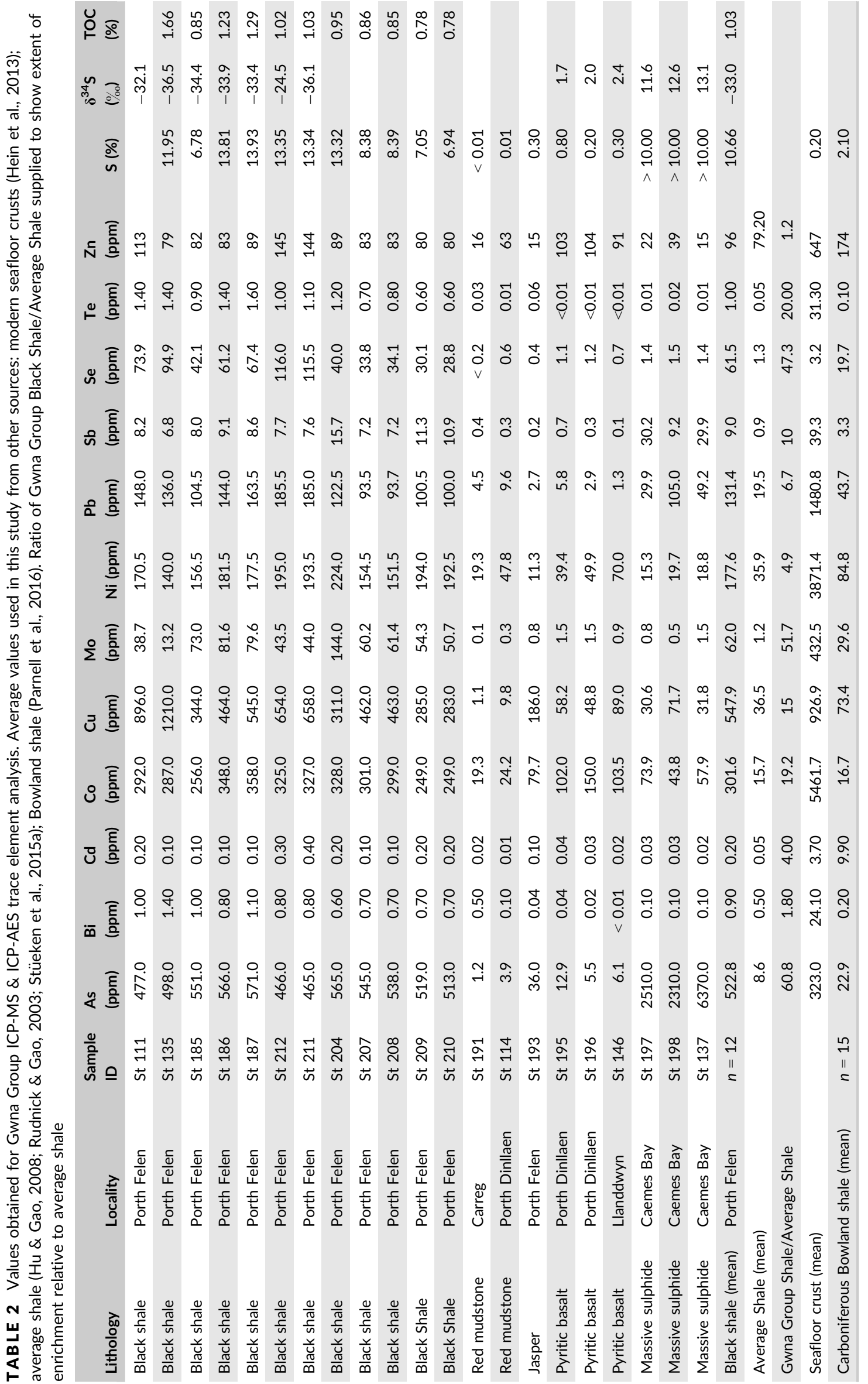




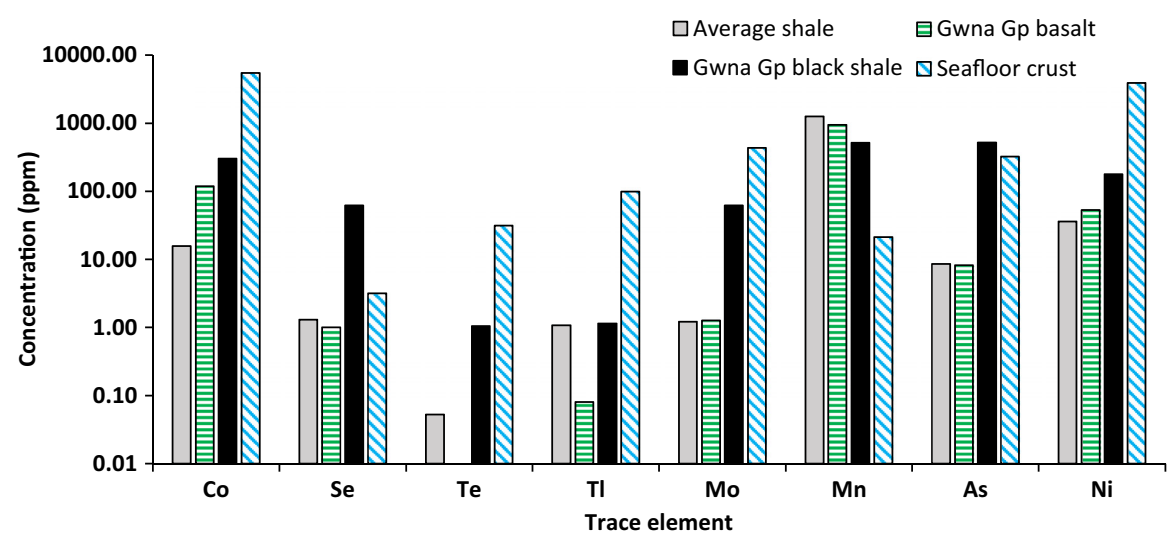

FIGURE 4 Comparison of Trace Element Concentrations-Key ICP-AES results for Porth Felen black shales $(n=12)$ and pyritic basalt samples $(n=3$ ), compared to published values for average shale and average modern seafloor crust (Hein et al., 2013; Hu \& Gao, 2008; Rudnick \& Gao, 2003; Stüeken et al., 2015a) [Colour figure can be viewed at wileyonlinelibrary.com]

shale values (Hu \& Gao, 2008; Rudnick \& Gao, 2003; Stüeken, Foriel, Buick, \& Schoepfer, 2015a) (Table 2; Figure 4), while other metals show less significant enrichments. Pyritic basalts in the Gwna Group show enrichments of up to $150 \mathrm{ppm}$ Co, but contain no other significant element abundances. TOC concentrations of the black shale average $1 \%$ and sulphur average is $10.7 \%$.

Sulphides within the black shales exhibit much lighter isotopic compositions (mean $-33.0 \%, n=7$ ) than those in other Gwna Group facies, range +1.7 to $+13.1 \%$, $(n=6)$. The composition of seawater sulphate at the end of the Neoproterozoic was about +20 to $+30 \%$ (Ries, Fike, Pratt, Lyons, \& Grotzinger, 2009).

SEM analysis of pyrite in the Gwna Group black shales shows abundant inclusions of the lead selenide mineral clausthalite (PbSe) and separate phases of nickel-cobalt-arsenic (Ni-Co-As) sulphide mineralisation (Figure 5a). Pyrites occur in both framboidal and euhedral morphologies, with growth zoning in euhedral phases. Framboids are 5-10 $\mu \mathrm{m}$ in diameter and are disseminated throughout the Gwna Group black shale, while euhedral pyrites are generally larger $(0.05-2 \mathrm{~mm})$ and present as discrete lenses within the unit (Figure 5b). Clausthalite inclusions occur exclusively within the framboids, while $\mathrm{Ni-Co}-\mathrm{As}$ phases are limited to the euhedral morphologies. Euhedral pyrites are observed to overgrow the framboids (Figure 5c).

LA-ICP-MS confirms that Se within the black shale occurs as evenly distributed, discrete $\mathrm{PbSe}$ phases, associated with micronscale pyrite, while $\mathrm{Ni}-\mathrm{Co}-\mathrm{As}$ mineralisation trends with larger pyrite (Figure 6). Discrete telluride phases are rare, while Te and Se matrix concentrations average $0.9 \mathrm{ppm}$ and $29.4 \mathrm{ppm}$ respectively outside the pyrite phases.

\section{5 | DISCUSSION}

\section{1 | Trace element sources}

High trace element contents in Neoproterozoic black shales reflect high trace element availability in the ambient seawater during deposition. Sea floor magmatic activity is a feasible source of trace elements during Gwna Group shale deposition, particularly given the pillowed basalts underlying the sequence. The elevated concentration of $\mathrm{Co}_{\mathrm{O}}$ in these basaltic units (Figure 4) also suggests a potential magmatic trace element source. However, a magmatic origin is unlikely because (1) abundance of Te in the basalts is low, while high Te is observed in the black shales, and (2) $\delta^{34} S$ obtained from pyrite in Gwna Group basalts and massive sulphides is much heavier than in the black shale.

The light $\delta^{34} S$ for pyrite in the Gwna Group shale, representing a fractionation of over $50 \%$ from Ediacaran seawater (Ries et al., 2009), indicates microbial sulphate reduction. Microbial sulphate reduction is considered to be the first in a sequence of stages of metal concentration from sedimentation to diagenesis, metamorphism and ultimately ore formation in orogenic gold deposits (Chang, Large, \& Maslennikov, 2008; Gaboury, 2013; Tomkins, 2013).

Analysis of pyrites from other black shales (Large et al., 2014, 2015) indicates that significant fluctuations in trace element chemistry of the oceans have occurred through time with high concentrations of Co, Mo and Se recorded during the late Ediacaran. Black shales would have been a key environment for the accumulation of these elements during times of enrichment in the oceans.

\section{2 | Sulphide mineralisation}

The two distinct morphologies and trace element enrichments of the pyrite in the Gwna Group black shale indicate at least two separate phases of mineralisation (Figure 5; Figure 6). Pyrite framboids are indicative of early stage microbial sulphate reduction in anoxic seafloor conditions (Schoonen, 2004), while cross-cutting relationships indicate that euhedral pyrites formed after the framboidal morphology. Euhedral pyrites likely formed during diagenesis, overgrowing and recrystallising the original depositional pyrite. Selenide $\left(\mathrm{Se}^{2-}\right)$ inclusions are found exclusively in the framboidal pyrite and therefore the high Se concentration of these black shales can be considered an early depositional signature. $\mathrm{Ni}$-Co-As inclusions are 

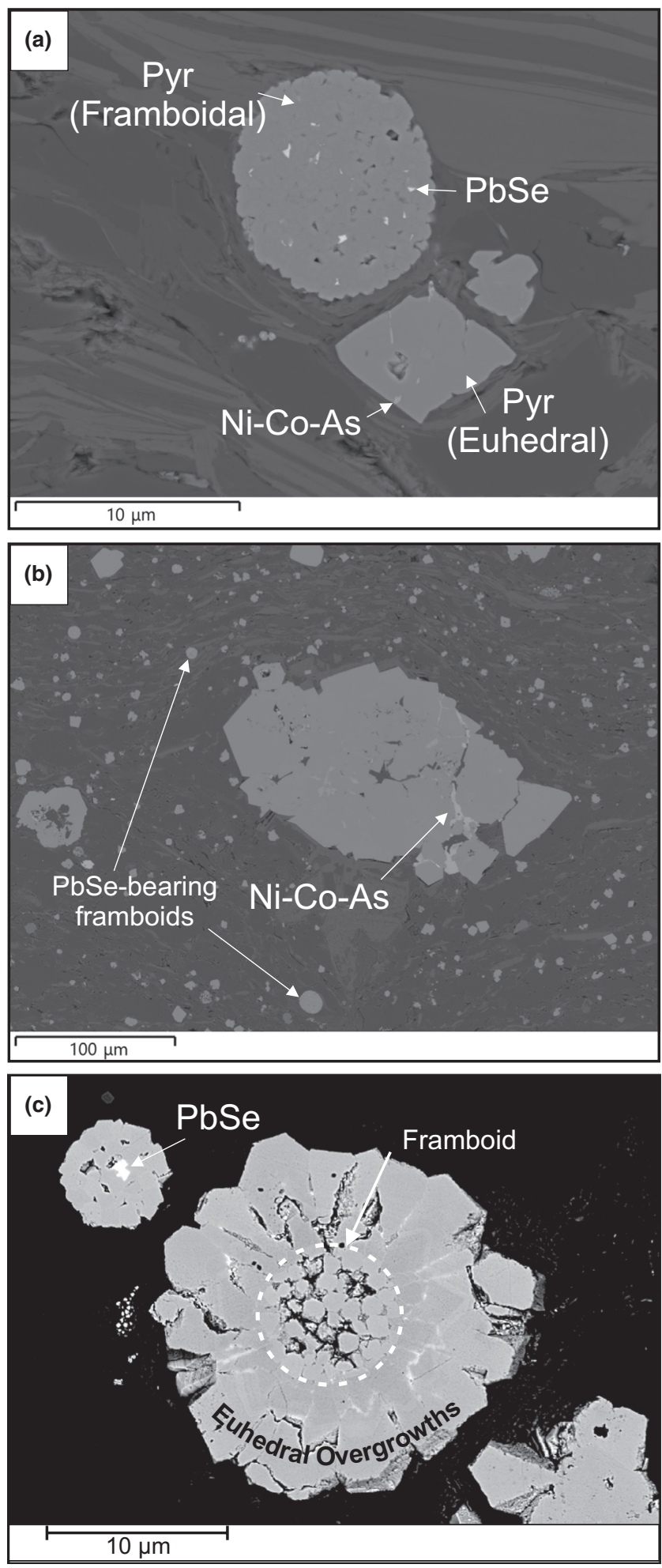

FIGURE 5 SEM imagery of pyritic morphologies and associated $\mathrm{PbSe}$ and $\mathrm{Ni}-\mathrm{Co}-$ As mineral sulphide inclusions in Gwna Group black shale: (a) Backscatter image of framboidal and euhedral pyrite (pyr) morphologies; (b) Large Ni-Co-As bearing euhedral pyrites with smaller disseminated pyrite framboids in surrounding matrix; (c) Central framboidal pyrite, with euhedral pyrite overgrowths unrelated to the depositional enrichment in Se and may represent re-mobilisation from the underlying pyritic mid-ocean ridge basalt.

LA-ICP-MS indicates that Te and Se are present in the sample matrix above typical concentrations, likely occurring as organically bound complexes indicative of increased $\mathrm{Te}$ and $\mathrm{Se}$ accumulation during shale deposition.

\section{3 | Accumulation rates}

The enrichments in $\mathrm{Te}$, Mo and $\mathrm{Co}$ in the black shale bear comparison with the enrichments found in the ferromanganese seafloor deposits, although the black shales have less extreme enrichments. Ferromanganese crusts and black shales represent oxidising and reducing depositional conditions respectively, with alternate mechanisms enriching the same elements (Figure 7) (Hein et al., 2003; Large et al., 2015). Ferromanganese crusts sequester elements through the formation and precipitation of $\mathrm{Fe}$ and manganese oxyhydroxide complexes on the sea floor. Black shales accumulate similar elements through the formation of reduced sulphide phases and the preservation of organically bound metal complexes (Brown \& Calas, 2012; Hein, Mizell, Koschinsky, \& Conrad, 2013).

Ferromanganese crusts are products of extremely slow sedimentation rates (1-10 mm/Ma; Hein et al., 2000), while black shales accumulate about 1,000 times faster (1-10 m/Ma; Stow, Huc, \& Bertrand, 2001), though still slowly for sedimentary deposition. The extreme enrichment of $\mathrm{Te}$ in ferromanganese crusts (average $31 \mathrm{ppm}$ ) reflects the extremely slow precipitation rate of these deposits (Hein et al., 2003; Kashiwabara et al., 2014). Taking into account a potential three orders of magnitude difference in sedimentation rate, the sequestration rate of $\mathrm{Te}$ is greater in the black shale of the Gwna Group. Assuming mean Te concentrations (Table 2), sedimentation rates of $10 \mathrm{~mm} / \mathrm{Ma}$ and $10 \mathrm{~m} / \mathrm{Ma}$ (Hein et al., 2000; Stow et al., 2001) respectively for the ferromanganese crusts and shales (both high end of range), a crust density of $1.3 \mathrm{~g} / \mathrm{cm}^{3}$ (Hein et al., 2000) and a measured shale density of $3.14 \mathrm{~g} / \mathrm{cm}^{3}$, the sequestration rates are 3.2 and 245 nmols Te $\mathrm{m}^{-2} \mathrm{a}^{-1}$ respectively. This suggests that in ancient successions, where both oxic and anoxic facies occur, Te accumulation will be favoured in anoxic, carbonaceous deposits.

\subsection{Implications}

Fluctuations in the trace element abundances of deep marine black shales have been used to infer variations in atmospheric oxygenation levels through time (Chen et al., 2015; Johnson et al., 2017; Large et al., 2015; Pogge von Strandmann et al., 2015; Reinhard et al., 2013; Stüeken et al., 2015a). A significant increase in selenium abundance within sedimentary pyrite globally has been identified from 580 to $470 \mathrm{Ma}$ (Large et al., 2017). 

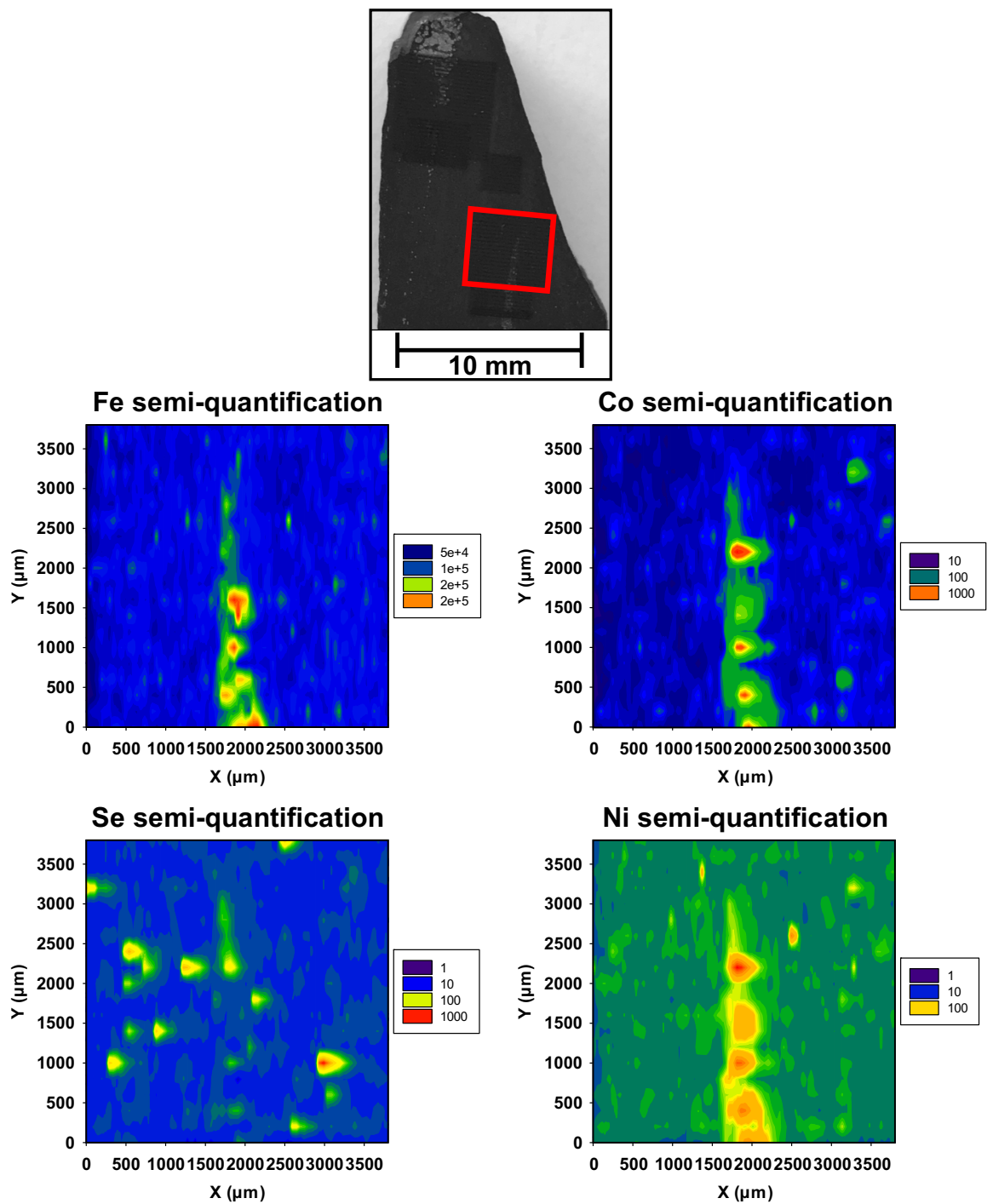

Te semi-quantification
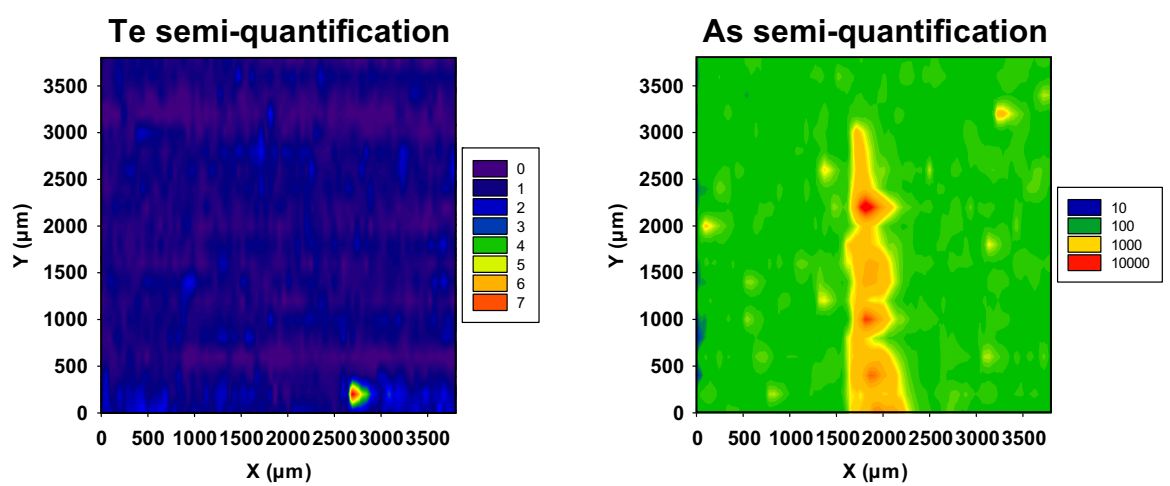

FIGURE 6 Semi-quantitative laser ablation ICP-MS element abundance maps for Fe, Se, Te, Co, Ni, As in Gwna Group black shale. Fe map indicates areas of pyritisation. $\mathrm{Co}, \mathrm{Ni}$ and As elemental distributions are very similar, while Se distribution shows disseminated inclusions throughout site and not associated with the larger pyrite abundances, with a relatively high matrix Se concentration averaging 29.4 ppm. Te map shows one minor area of concentrated Te mineralisation, with a high Te matrix concentration averaging 0.9 ppm [Colour figure can be viewed at wileyonlinelibrary.com]

The age of deposition for Gwna Group (570-580 Ma) coincides with the late Neoproterozoic GOE2 (Campbell \& Squire, 2010; Canfield, 2005; Lyons, Reinhard, \& Planavsky, 2014) and the appearance of complex Ediacaran organisms at $575 \mathrm{Ma}$ (Canfield, Poulton, \& Narbonne, 2007). The increase in atmospheric oxygen levels at the end of the Neoproterozoic has been proposed as a driver for the evolution of complex life and the Cambrian explosion (Pogge von Strandmann et al., 2015). Trace element increases in the Ediacaran oceans have been correlated with the amalgamation of Gondwana and subsequent erosion of material from the associated orogenic 


\section{Deep marine shale deposition}
Modern seafloor
crust formation

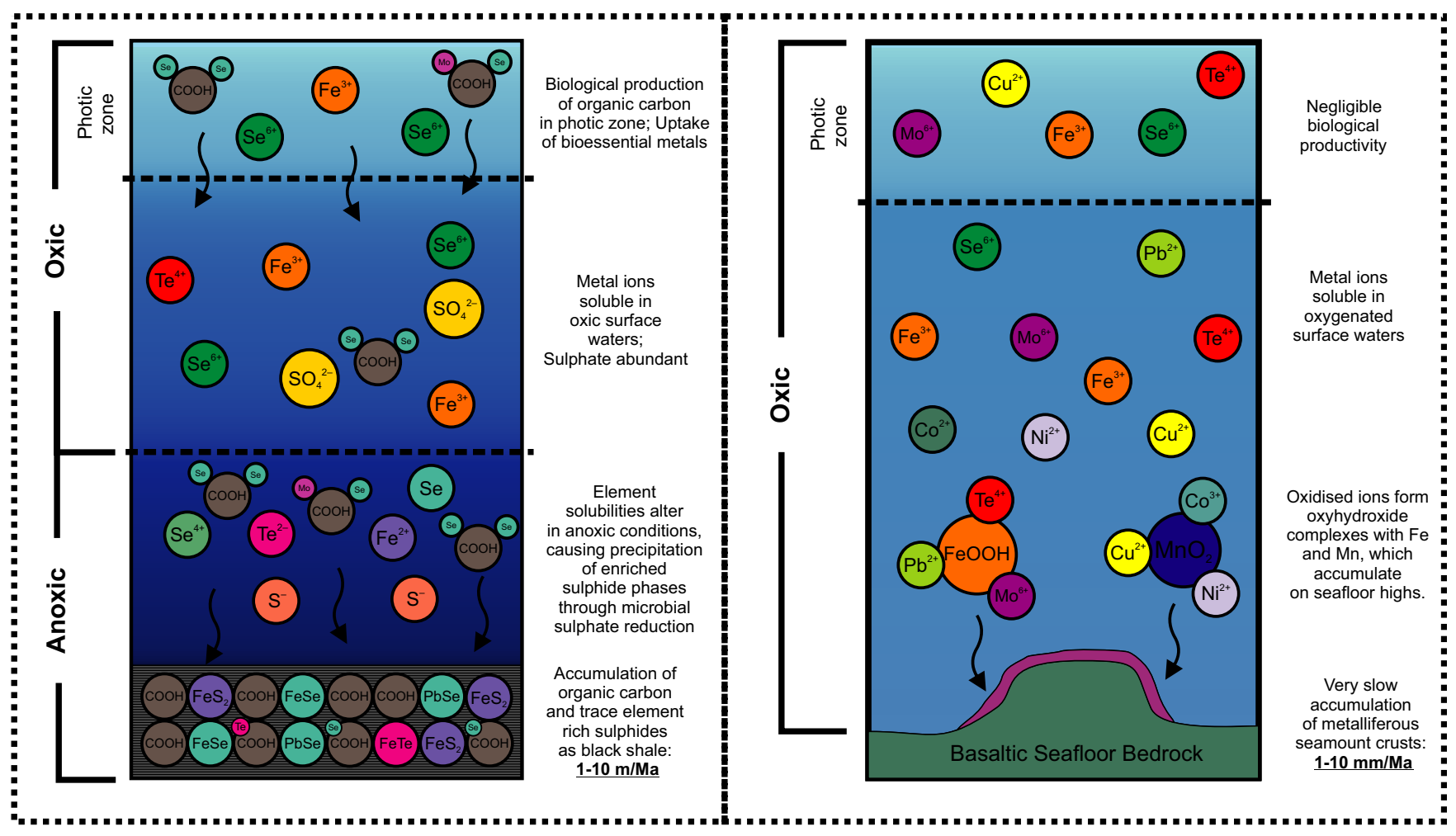

FIGURE 7 Comparison of depositional models for anoxic deep marine black shale and oxic modern seafloor crust. Variations in trace element sequestration systems illustrated in relation to changes in oxidation state of elements with varying oxygen availability and the contribution of organic matter adsorption (Brown \& Calas, 2012). 'Modern Seafloor Crust Formation' adapted from Hein et al. (2013) [Colour figure can be viewed at wileyonlinelibrary.com]

belts, indicated by a large increase in seawater ${ }^{87} \mathrm{Sr} /{ }^{86} \mathrm{Sr}$ (Campbell \& Squire, 2010).

Elevated sediment influx into ocean waters increased the availability of bioessential elements, including Se, which increased photosynthetic activity at the Gondwanan continental margins. This resulted in higher organic carbon (and Se) deposition into Ediacaran ocean sediments (Campbell \& Squire, 2010; Pogge von Strandmann et al., 2015). The corresponding $\mathrm{O}_{2}$ release into the atmosphere produced a positive feedback loop (Figure 2), leading to further enhanced chemical weathering of continents and trace element supply to the oceans.

The significant concentration of Se (up to $116 \mathrm{ppm}$ ) in the Gwna Group black shales supports the model of increased trace element drawdown into anoxic marine deposits during the Ediacaran, associated with increased photosynthetic activity and higher atmospheric $\mathrm{O}_{2}$ concentrations.

Average TOC values of $1 \%$ in the Gwna Group black shale and an average Mo abundance of $64 \mathrm{ppm}$ are indicative of intermittently euxinic depositional conditions (Scott \& Lyons, 2012). The abundant pyrite content of these black shales (average $S=10.7 \%$ ) is an indicator of anoxic to euxinic marine floor conditions (Berner \& Raiswell, 1984) and an indicator of significant atmospheric oxygenation through sulphide production (Canfield, 2005). The best model for the depositional environment for the Gwna Group black shales is a stratified anoxic sub-basin within a widely oxic oceanic environment (Canfield et al., 2008; Stüeken et al., 2015b). The forearc trench along the Proto-Gondwanan continental margin (Campbell \& Squire, 2010) is proposed as the most likely depositional position for these black shales (Figure 2), providing a deepened ocean setting and proximity to photosynthetic activity (Maruyama et al., 2010).

The enrichments of Te, Co and Se within the Gwna Group shale suggest that other black shales in the Proterozoic and lower Palaeozoic deserve further study for their content of critical elements, specifically those deposited during periods of significant atmospheric fluctuations (Johnson et al., 2017; Large et al., 2014; Tomkins, 2013). This suggests the potential for other types of mineral-bearing deposit based on black shale protoliths deposited during key time periods (Coveney \& Nansheng, 1989; Giordano, 1989; Large, Bull, \& Maslennikov, 2011; Pedersen, Nielsen, Boyce, \& Fallick, 2003; Wagner \& Boyce, 2003), particularly where supergene processes may have resulted in small-scale ore deposits near surface.

\section{6 | CONCLUSIONS}

Enrichments of critical elements in the black shales of the Gwna Group show a similarity to those recorded in metalliferous seafloor 
crusts. Heterogeneous enrichments within the Gwna Group black shales indicate that the high Se and Te concentrations are depositional in origin and can be utilised to provide evidence for increased photosynthetic activity during the GOE2. Black shales of comparable origin and timing relative to major atmospheric oxygenation events may have acted as protoliths for ore deposits currently unrecognised, emphasising the value of black shales in ore exploration.

\section{ACKNOWLEDGEMENTS}

We are grateful to John Still for his skilled technical support and the ACEMAC facility at the University of Aberdeen. Research funded by NERC grant NE/M010953/1 and NERC facility grant IP-1631-0516. AJB is funded by NERC support of the Isotope Community Support Facility SUERC. The authors thank Eva Stüeken, Ross Large and one anonymous reviewer for their constructive feedback on the original manuscript.

\section{ORCID}

Joseph G. T. Armstrong (iD http://orcid.org/0000-0002-1342-3710

\section{REFERENCES}

Berner, R. A., \& Raiswell, R. (1984). C/S method for distinguishing freshwater from marine sedimentary rocks. Geology, 12, 365-368. https:// doi.org/10.1130/0091-7613(1984)12<365:CMFDFF>2.0.CO;2

Brown, G. E. Jr, \& Calas, G. (2012). Mineral-Aqueous solution interfaces and their impact on the environment. Geochemical Perspectives, 1, 483-742. https://doi.org/10.7185/geochempersp.1.4

Bullock, L. A., Parnell, J., Perez, M., Boyce, A., Feldmann, J., \& Armstrong, J. G. T. (2018). Multi-stage pyrite genesis and epigenetic selenium enrichment of Greenburn coals (East Ayrshire). Scottish Journal of Geology, 58, https://doi.org/10.1144/sjg2017-010

Campbell, I. H., \& Squire, R. J. (2010). The mountains that triggered the Late Neoproterozoic increase in oxygen: The Second Great Oxidation Event. Geochimica et Cosmochimica Acta, 74, 4187-4206. https://doi. org/10.1016/j.gca.2010.04.064

Canfield, D. E. (2005). The early history of atmospheric oxygen: Homage to Robert M. Garrels. Annual Review of Earth and Planetary Sciences, 33, 1-36. https://doi.org/10.1146/annurev.earth.33. 092203.122711

Canfield, D. E., Poulton, S. W., Knoll, A. H., Narbonne, G. M., Ross, G., Goldberg, T., \& Strauss, H. (2008). Ferruginous conditions dominated later neoproterozoic deep-water chemistry. Science, 321, 949-952. https://doi.org/10.1126/science.1154499

Canfield, D. E., Poulton, S. W., \& Narbonne, G. M. (2007). Late-Neoproterozoic deep-ocean oxygenation and the rise of animal life. Science, 315, 92-95. https://doi.org/10.1126/science.1135013

Chang, Z., Large, R. R., \& Maslennikov, V. (2008). Sulfur isotopes in sediment-hosted orogenic gold deposits: Evidence for an early timing and a seawater sulfur source. Geology, 36, 971-974. https://doi.org/10. 1130/G25001A.1

Chelvanathan, P., Hossain, M. I., \& Amin, N. (2010). Performance analysis of copper-indium-gallium-diselenide (CIGS) solar cells with various buffer layers by SCAPS. Current Applied Physics, 10, 387-391. https://doi.org/10.1016/j.cap.2010.02.018

Chen, X., Ling, H.-F., Vance, D., Shields-Zhou, G.A., Zhu, M., Poulton, S.W., ... Archer, C. (2015). Rise to modern levels of ocean oxygenation coincided with the Cambrian radiation of animals. Nature Communications, 6, 1-7, doi: 10.1038/ncomms8142.

Coveney, R. M., \& Nansheng, C. (1989). Nickel-Molybdenum-PlatinumGold Deposits in Black Shales of Southern China - A New Ore Type with Possible Analogs in Pennsylvanian Rocks of the U.S.A. In: R. I. Grauch \& H. L. O. Huyck (Eds.), Metalliferous Black Shales and Related Ore Deposits - Proceedings (pp. 9-11). Denver: USGS.

Gaboury, D. (2013). Does gold in orogenic deposits come from pyrite in deeply buried carbon-rich sediments?: Insight from volatiles in fluid inclusions. Geology, 41, 1207-1210. https://doi.org/10.1130/ G34788.1

Giordano, T. H. (1989). Organic Ligands and Metal-Organic Complexing in Ore Fluids of Sedimentary Origin. In: R. I. Grauch \& H. L. O. Huyck (Eds.), Metalliferous Black Shales and Related Ore Deposits - Proceedings (pp. 31-41). Denver: USGS.

Gradstein, F. M., \& Ogg, J. G. (2012). The Chronostratigraphic Scale. In F. M. Gradstein, J. G. Ogg, M. D. Schmitz, \& G. M. Ogg (Eds.), The Geologic Time Scale 2012 (pp. 31-42). Oxford: Elsevier.

Hein, J. R., Conrad, T. A., \& Staudigel, H. (2010). Seamount mineral deposits. Oceanography, 23, 184-189. https://doi.org/10.5670/ocea nog. 2010.70

Hein, J. R., Koschinsky, A., Bau, M., \& Roberts, L. (2000). Cobalt-Rich Ferromanganese Crusts in the Pacific. In D. S. Cronan (Ed.), Handbook of Marine Mineral Deposits (pp. 239-279). Boca Raton: CRC Press.

Hein, J. R., Koschinsky, A., \& Halliday, A. N. (2003). Global occurrence of tellurium-rich ferromanganese crusts and a model for the enrichment of tellurium. Geochimica et Cosmochimica Acta, 67, 1117-1127. https://doi.org/10.1016/S0016-7037(00)01279-6

Hein, J. R., Mizell, K., Koschinsky, A., \& Conrad, T. A. (2013). Deep-ocean mineral deposits as a source of critical metals for high- and greentechnology applications: Comparison with land-based resources. Ore Geology Reviews, 51, 1-14. https://doi.org/10.1016/j.oregeorev.2012. 12.001

Horák, J. M., \& Evans, J. A. (2011). Early Neoproterozoic limestones from the Gwna Group, Anglesey. Geological Magazine, 148, 78-88, doi: 10. 1017/S0016756810000464.

Howells, M. F. (2007). British regional geology: Wales (BGS, ed.): Keyworth, Nottingham: British Geological Survey.

Hu, Z., \& Gao, S. (2008). Upper crustal abundances of trace elements: A revision and update. Chemical Geology, 253, 205-221. https://doi. org/10.1016/j.chemgeo.2008.05.010

Johnson, S. C., Large, R. R., Coveney, R. M., Kelley, K. D., Slack, J. F., Steadman, J. A., ... Meffre, S. (2017). Secular distribution of highly metalliferous black shales corresponds with peaks in past atmosphere oxygenation. Mineralium Deposita, 52, 791-798. https://doi.org/10. 1007/s00126-017-0735-7

Kashiwabara, T., Oishi, Y., Sakaguchi, A., Sugiyama, T., Usui, A., \& Takahashi, Y. (2014). Chemical processes for the extreme enrichment of tellurium into marine ferromanganese oxides. Geochimica et Cosmochimica Acta, 131, 150-163. https://doi.org/10.1016/j.gca.2014. 01.020

Kawai, T., Windley, B. F., Terabayashi, M., Yamamoto, H., Isozaki, Y., \& Maruyama, S. (2008). Neoproterozoic glaciation in the mid-oceanic realm: An example from hemi-pelagic mudstones on Llanddwyn Island, Anglesey, UK. Gondwana Research, 14, 105-114. https://doi. org/10.1016/j.gr.2007.12.008

Kawai, T., Windley, B. F., Terabayashi, M., Yamamoto, H., Maruyama, S., Omori, S., ... Isozaki, Y. (2007). Geotectonic framework of the Blueschist Unit on Anglesey-Lleyn, UK, and its role in the development of a Neoproterozoic accretionary orogen. Precambrian Research, 153, 11-28. https://doi.org/10.1016/j.precamres.2006.11.002

Large, R. R., Bull, S. W., \& Maslennikov, V. V. (2011). A carbonaceous sedimentary source rock model for Carlin-type and orogenic gold deposits. Economic Geology, 106, 331-358. https://doi.org/10.2113/ econgeo.106.3.331 
Large, R.R., Halpin, J.A., Danyushevsky, L. V., Maslennikov, V. V., Bull, S.W., \& Long, J.A, ... Calver, C.R. (2014). Trace element content of sedimentary pyrite as a new proxy for deep-time ocean-atmosphere evolution. Earth and Planetary Science Letters, 389, 209-220, doi: 10. 1016/j.epsl.2013.12.020.

Large, R.R., Halpin, J.A., Lounejeva, E., Danyushevsky, L. V., Maslennikov, V. V., \& Gregory, D, .. Stepanov, A.S. (2015). Cycles of nutrient trace elements in the Phanerozoic ocean. Gondwana Research, 28, 1282-1293, doi: 10.1016/j.gr.2015.06.004.

Large, R. R., Mukherjee, I., Gregory, D. D., Steadman, J. A., Maslennikov, V. V., \& Meffre, S. (2017). Ocean and atmosphere geochemical proxies derived from trace elements in marine pyrite: Implications for ore genesis in sedimentary basins. Economic Geology, 112, 423-450. https://doi.org/10.2113/econgeo.112.2.423

Leite, S., Luis, P., Carvalho, G., Rodrigues, L., Lemos, D., Barbosa, A., \& Dias, G. (2017). Hydrometallurgy Hydrometallurgical separation of copper and cobalt from lithium-ion batteries using aqueous twophase systems. Hydrometallurgy, 169, 245-252. https://doi.org/10. 1016/j.hydromet.2017.01.002

Lyons, T. W., Reinhard, C. T., \& Planavsky, N. J. (2014). The rise of oxygen in Earth's early ocean and atmosphere. Nature, 506, 307-315. https://doi.org/10.1038/nature13068

Maruyama, S., Kawai, T., \& Windley, B. F. (2010). Ocean plate stratigraphy and its imbrication in an accretionary orogen: The Mona Complex, Anglesey-Lleyn, Wales, UK. Geological Society, London, Special Publications, 338, 55-75. https://doi.org/10.1144/SP338.4

Meert, J. G., \& Lieberman, B. S. (2008). The Neoproterozoic assembly of Gondwana and its relationship to the Ediacaran-Cambrian radiation. Gondwana Research, 14, 5-21. https://doi.org/10.1016/j.gr.2007.06. 007

Morales-Acevedo, A. (2006). Thin film CdS/CdTe solar cells: Research perspectives. Solar Energy, 80, 675-681. https://doi.org/10.1016/ j.solener.2005.10.008

Nassar, N. T., Graedel, T. E., \& Harper, E. M. (2015). By-product metals are technologically essential but have problematic supply. Science Advances, 1, 1-10. https://doi.org/10.1126/sciadv.1400180

Parnell, J., Brolly, C., Spinks, S., \& Bowden, S. (2016). Selenium enrichment in Carboniferous Shales, Britain and Ireland: Problem or opportunity for shale gas extraction? Applied Geochemistry, 66, 82-87. https://doi.org/10.1016/j.apgeochem.2015.12.008

Parnell, J., Perez, M., Armstrong, J., Bullock, L., Feldmann, J., \& Boyce, A. J. (2017). A black shale protolith for gold-tellurium mineralisation in the Dalradian Supergroup (Neoproterozoic) of Britain and Ireland. Applied Earth Science, 126, 161-175. https://doi.org/10.1080/ 03717453.2017.1404682

Pedersen, M., Nielsen, J. K., Boyce, A. J., \& Fallick, A. E. (2003). Timing and genesis of base-metal mineralisation in black shales of the Upper Permian Ravnefjeld Formation, Wegener Halvø, East Greenland. Mineralium Deposita, 38, 108-125. https://doi.org/10.1007/s00126-0020283-6

Pogge von Strandmann, P. A. E., Stüeken, E. E., Elliott, T., Poulton, S. W., Dehler, C. M., Canfield, D. E., \& Catling, D. C. (2015). Selenium isotope evidence for progressive oxidation of the Neoproterozoic biosphere. Nature Communications, 6, 10157. https://doi.org/10.1038/nc omms10157

Reinhard, C. T., Planavsky, N. J., Robbins, L. J., Partin, C. A., Gill, B. C., Lalonde, S. V., ... Lyons, T. W. (2013). Proterozoic ocean redox and biogeochemical stasis. Proceedings of the National Academy of Sciences, 110, 5357-5362. https://doi.org/10.1073/pnas. 1208622110

Ries, J. B., Fike, D. A., Pratt, L. M., Lyons, T. W., \& Grotzinger, J. P. (2009). Superheavy pyrite $\left(\delta^{34} S_{\text {pyr }}>\delta^{34} S_{\text {CAS }}\right)$ in the terminal Proterozoic Nama Group, southern Namibia: A consequence of low seawater sulfate at the dawn of animal life. Geology, 37, 743-746. https://doi. org/10.1130/G25775A.1
Rudnick, R. L., \& Gao, S. (2003). Composition of the continental crust. In H. D. Holland, \& K. K. Turekian (Eds.), Treatise on Geochemistry (pp. 1-64). B.V.: Elsevier.

Sato, T., Sawaki, Y., Asanuma, H., Fujisaki, W., Okada, Y., Maruyama, S., ... Windley, B. F. (2015). Redox condition of the late Neoproterozoic pelagic deep ocean: ${ }^{57} \mathrm{Fe}$ Mössbauer analyses of pelagic mudstones in the Ediacaran accretionary complex, Wales, UK. Tectonophysics, 662, 472-480. https://doi.org/10.1016/j.tecto.2015.08.002

Schoonen, M. A. A. (2004). Mechanisms of sedimentary pyrite formation. Geological Society of America, SP, 379, 117-134. https://doi.org/10. 1130/0-8137-2379-5.117

Scott, C., \& Lyons, T. W. (2012). Contrasting molybdenum cycling and isotopic properties in euxinic versus non-euxinic sediments and sedimentary rocks: Refining the paleoproxies. Chemical Geology, 324-325, 19-27. https://doi.org/10.1016/j.chemgeo.2012.05.012

Stow, D. A. V., Huc, A. Y., \& Bertrand, P. (2001). Depositional processes of black shales in deep water. Marine and Petroleum Geology, 18, 491-498. https://doi.org/10.1016/S0264-8172(01)00012-5

Stüeken, E.E., Buick, R., Bekker, A., Catling, D., Foriel, J., \& Guy, B.M, ... Poulton, S.W. (2015b). The evolution of the global selenium cycle: Secular trends in Se isotopes and abundances. Geochimica et Cosmochimica Acta, 162, 109-125, doi: 10.1016/j.gca.2015.04.033.

Stüeken, E. E., Foriel, J., Buick, R., \& Schoepfer, S. D. (2015a). Selenium isotope ratios, redox changes and biological productivity across the end-Permian mass extinction. Chemical Geology, 410, 28-39. https://doi.org/10.1016/j.chemgeo.2015.05.021

Tomkins, A. G. (2013). A biogeochemical influence on the secular distribution of orogenic gold. Economic Geology, 108, 193-197. https://d oi.org/10.2113/econgeo.108.2.193

Vesborg, P. C. K., \& Jaramillo, T. F. (2012). Addressing the terawatt challenge: Scalability in the supply of chemical elements for renewable energy. RSC Advances, 2, 7933-7947. https://doi.org/10.1039/c2ra20839c

Wagner, T., \& Boyce, A. J. (2003). Sulphur isotope geochemistry of black shale-hosted antimony mineralization, Arnsberg, northern Rhenish Massif, Germany. Journal of the Geological Society, 160, 299-308. https://doi.org/10.1144/0016-764902-010

Wood, M., \& Nicholls, G. D. (1973). Precambrian Stromatolitic Limestones from Northern Anglesey. Nature Physical Science, 241, 65. https://doi.org/10.1038/physci241065a0

Xu, G., Hannah, J. L., Bingen, B., Georgiev, S., \& Stein, H. J. (2012). Digestion methods for trace element measurements in shales: Paleoredox proxies examined. Chemical Geology, 324-325, 132-147. https://doi. org/10.1016/j.chemgeo.2012.01.029

\section{SUPPORTING INFORMATION}

Additional Supporting Information may be found online in the supporting information tab for this article.

Data S1. Sigma 1 errors and limits of detection (LOD) for the analytical techniques used in the study.

How to cite this article: Armstrong JGT, Parnell J, Bullock LA, Perez M, Boyce AJ, Feldmann J. Tellurium, selenium and cobalt enrichment in Neoproterozoic black shales, Gwna Group, UK: Deep marine trace element enrichment during the Second Great Oxygenation Event. Terra Nova. 2018;30:244 253. https://doi.org/10.1111/ter.12331 